\title{
Effect of domestication on microorganism diversity and anaerobic digestion of food waste
}

\author{
S.J. Bi ${ }^{1}$, X.J. Hong ${ }^{2}$, G.X. Wang ${ }^{1}$, Y. Li ${ }^{1}$, Y.M. Gao ${ }^{1}$, L. Yan ${ }^{1}$, Y.J. Wang1* \\ and W.D. Wang ${ }^{1 *}$ \\ ${ }^{1}$ College of Life Science and Technology, \\ Heilongjiang Bayi Agricultural University, Daqing, Heilongjiang, China \\ ${ }^{2}$ Commission of Agriculture of Daqing City, \\ Ministry of Agriculture, Daqing, Heilongjiang, China \\ *These authors contributed equally to this study. \\ Corresponding authors: Y.J. Wang / W.D. Wang \\ E-mail: wangyanjie1972@163.com / wwdcyy@126.com
}

Genet. Mol. Res. 15 (3): gmr.15038417

Received January 11, 2016

Accepted March 18, 2016

Published August 18, 2016

DOI http://dx.doi.org/10.4238/gmr.15038417

Copyright (C) 2016 The Authors. This is an open-access article distributed under the terms of the Creative Commons Attribution ShareAlike (CC BY-SA) 4.0 License

\begin{abstract}
To accomplish the rapid start-up and stable operation of biogas digesters, an efficient inoculum is required. To obtain such an inoculum for food waste anaerobic digestion, we domesticated dairy manure anaerobic digestion residue by adding food waste every day. After 36 days, the $\mathrm{pH}$ and biogas yield stabilized signifying the completion of domestication. During domestication, the microbial communities in the inocula were investigated by constructing $16 \mathrm{~S}$ rDNA clone libraries. We evaluated the effect of the domesticated inoculum by testing batch food waste anaerobic digestion with a non-domesticated inoculum as a control. The $\mathrm{pH}$ and methane yield of the digestion systems were determined as measurement indices. Domestication changed the composition and proportion of bacteria and archaea in the inocula. Of the bacteria, Clostridia (49.3\%), Bacteroidales (19.5\%),
\end{abstract}


and Anaerolinaceae $(8.1 \%)$ species were dominant in the seed sludge; Anaerolinaceae (49.0\%), Clostridia (28.4\%), and Bacteroidales (9.1\%), in domestication sludge. Methanosaeta was the dominant genus in both of the seed $(94.3 \%)$ and domestication (74.3\%) sludge. However, the diversity of methanogenic archaea was higher in the domestication than in seed sludge. Methanoculleus, which was absent from the seed sludge, appeared in the domestication sludge (21.7\%). When the domesticated inoculum was used, the digestion system worked stably (organic loading rate: $20 \mathrm{gVS} / \mathrm{L}$; methane yield: $292.2 \pm 9.8 \mathrm{~mL} / \mathrm{gVS}$; $\mathrm{VS}=$ volatile solids), whereas the digestion system inoculated with seed sludge failed to generate biogas. The results indicate that inoculum domestication ensures efficient and stable anaerobic digestion by enriching the methanogenic strains.

Key words: Food waste; Biogas; Inoculum; Domesticated inoculum

\section{INTRODUCTION}

Energy is essential for industrial production and everyday life. Renewable energy from biogas waste can enhance energy security, reduce pollution, and control greenhouse gases, especially in developing countries. The amount of food waste (FW) produced by canteens, restaurants, companies, and families increases dramatically with population growth and rising living standards (Chen and $\mathrm{Gu}, 2012$ ). China produced about 90 million tons of $\mathrm{FW}$ in 2010; this number grows by more than $10 \%$ every year (Yang et al., 2015). FW is an easily biodegradable substrate owing to its high organic and moisture contents. Traditionally, FW has been disposed of mainly through landfills, animal feeding, and aerobic composting (Carlsson et al., 2015; Suwannarat and Ritchie, 2015). FW disposal has caused serious environmental problems in many countries. Anaerobic digestion (AD) is an alternative disposal method for FW that can efficiently generate biogas for renewable energy in a controlled environment (Zhang et al., 2014a).

Microorganisms use four consecutive complex steps (hydrolysis, acidogenesis, acetogenesis, and methanogenesis) during the anaerobic degradation of organic material to biogas (Zhang et al., 2015). In general, these microorganisms can be classified as acidogenic or methanogenic. During the degradation process, volatile fatty acids (VFAs) are formed by acidogenic microorganisms, whereas the methanogenic microorganisms convert VFAs into methane and carbon dioxide. In general, food waste is easily biodegradable through AD because it has high water, fat, protein, and crude fiber contents (Chen et al., 2016). If the VFAs produced by bacterial hydrolysis are not quickly consumed, VFA accumulation inhibits the function of methanogens, resulting in process failure.

The start-up of an anaerobic digester is the critical step for organic matter AD. Factors such as temperature, $\mathrm{pH}$, organic loading rate (OLR), hydraulic retention time (HRT), and nutrient balance can influence the AD process (Jain et al., 2015; Xu et al., 2015). The microbial community and inoculum quality used for the start-up of an anaerobic reactor are also critical factors for successful biogas production (Elbeshbishy et al., 2012; Kong et al., 2016). The effluent from the $\mathrm{AD}$ of manure or the anaerobic sludge from wastewater treatment plants

Genetics and Molecular Research 15 (3): gmr.15038417 
are typically used as inocula for FW AD. However, these inocula result in a difficult start-up process with low OLR. The rate of biogas production from the anaerobic digestion of FW is improved after inoculation with sludge acclimated by the addition of FW (Ma et al., 2007). Supaphol et al. (2011) reported that raw materials and environmental factors changed the composition of microorganisms during anaerobic fermentation, which affected fermentation efficiency. Zhou et al. (2004) found that the structure and composition of the microbial community in the inoculated sludge changed during the domestication process. The use of the optimal inoculum for the fermentation substrate is critical for improving biogas production (Nizami et al., 2012).

Therefore, in this study we obtained an efficient inoculum acclimated by FW addition. The domestication process was characterized, changes in the microbial community were analyzed, and the effects of the domestication inoculum on FW digestion were evaluated.

\section{MATERIAL AND METHODS}

\section{Characteristics of food waste and dairy manure}

FW was collected from the cafeteria of the Heilongjiang Bayi Agricultural University (HBAU) of Heilongjiang Province, China. The waste mainly comprised rice, meat, vegetables, oil, and some non-digestible substances such as plastics and bone, which were manually removed. The residual food waste was ground into 5-10-mm pieces using a mill (JJ-2B, Youlian, China). Dairy manure (DM) was collected from the HBAU dairy center. The pretreated $\mathrm{FW}$ and $\mathrm{DM}$ were then stored at $-20^{\circ} \mathrm{C}$. Before use, they were defrosted at $4{ }^{\circ} \mathrm{C}$ for $24 \mathrm{~h}$. Table 1 shows the characteristics of the manure and FW (average values and standard deviations of three samples).

Table 1. Characteristics of food waste (FW) and dairy manure (DM).

\begin{tabular}{l|c|c}
\hline Characteristic & FW & DM \\
\hline $\mathrm{pH}$ & $6.5 \pm 0.1$ & $22.3 \pm 0.1$ \\
\hline TS $(\%)$ & $24.2 \pm 0.2$ & $15.7 \pm 0.4$ \\
\hline VS $(\%)$ & $22.1 \pm 0.2$ & $68.6 \pm 0.3$ \\
\hline VS $/ \mathrm{TS}$ & $91.3 \pm 0.4$ & $49.7 \pm 0.4$ \\
\hline $\mathrm{C}(\% *)$ & $34.8 \pm 0.1$ & $3.5 \pm 0.1$ \\
\hline $\mathrm{N}(\% *)$ & $2.4 \pm 0.1$ & $29.6 \pm 0.7$ \\
\hline $\mathrm{C} / \mathrm{N}$ & $14.5 \pm 0.3$ & $3.5 \pm 0.1$ \\
\hline Ash $(\% *)$ & $8.7 \pm 0.4$ & $2.0 \pm 0.3$ \\
\hline Fat $(\% *)$ & $13.6 \pm 0.6$ & $64.9 \pm 0.9$ \\
\hline Protein $(\% *)$ & $14.5 \pm 0.4$ & \\
\hline Carbohydrates $(\% *)$ & $63.2 \pm 0.8$ & \\
\hline TS total & & \\
\hline
\end{tabular}

$\mathrm{TS}=$ total solids; VS $=$ volatile solids. $*$ Values are reported as means \pm standard deviation of triplicate samples.

\section{Experimental setup and procedures}

\section{0-L digester}

A 20-L synthetic glass mixed reactor with an effective volume of $18 \mathrm{~L}$ was used as the domestication reactor. The reactor was set up with the DM anaerobic digestion batch with a volatile solid (VS) content of $8 \%$ at a temperature of $35^{\circ} \pm 1{ }^{\circ} \mathrm{C}$. When the reactor 
stopped yielding biogas, the FW domestication process started, and the residue of the DM AD was collected as seed sludge (SS). The semi-continuous AD of FW was then carried out at a temperature of $35^{\circ} \pm 1^{\circ} \mathrm{C}$ with an OLR of $20 \mathrm{~g} \cdot \mathrm{L}^{-1} \cdot$ day $^{-1}$ and an HRT of 18 days. Each day, FW was pumped into the reactor using a peristaltic pump.

Before feeding, effluent was discharged from the reactor to maintain an 18-L working volume. This domestication process lasted 36 days; biogas and $\mathrm{pH}$ values were measured each day. FW AD residue was collected as domestication sludge (DS). The effluent samples were collected after each feeding and the discharge was directly monitored using a $\mathrm{pH}$ meter. Biogas was collected via a porthole located at the top of the reactor and measured using the water displacement method under standard conditions.

\section{1-L digester}

The batch $\mathrm{AD}$ was carried out in 1-L glass reactors with an effective volume of $0.8 \mathrm{~L}$ at $35^{\circ} \pm 1^{\circ} \mathrm{C}$. SS $(240 \mathrm{~mL})$ and $\mathrm{FW}(72.4 \mathrm{~g})$ were mixed, made up to $800 \mathrm{~mL}$ with tap water, and added to each digester. The reactor was purged with nitrogen for 6 min to guarantee an anaerobic environment.

Batch AD was conducted with two different inocula, SS and DS, to determine the effects of SS domestication on AD FW performance. Gas production, methane content, and $\mathrm{pH}$ were measured each day during the process. To eliminate the impact of single test results, each treatment was repeated three times.

\section{DNA extraction and conventional polymerase chain reaction (PCR)}

SS and DS samples were centrifuged at $8000 \mathrm{rpm}$ for $10 \mathrm{~min}$ for DNA extraction. Genomic DNA was extracted using an automated nucleic acid extractor (Bioteke Biotech Co., Ltd., Beijing, China) for use as the PCR template. The DNA was eluted with $40 \mathrm{~mL}$ Tris- $\mathrm{HCl}$ buffer, $\mathrm{pH} 8.0$, and stored at $20^{\circ} \mathrm{C}$ until required for the analysis. PCR amplification was performed using the GeneAmp PCR system (Model 9700, Applied Biosystems, USA). Bacterial community PCR amplification for clone analysis was conducted using the following primer combination: 27F (5'-AGAGTTTGATCCTGGCTCAG-3') and 1492R (5'-GGTTACCTTGTTACGACTT-3') (Kröber et al., 2009). The PCR regimen comprised: $10 \mathrm{~min}$ initial denaturing at $94^{\circ} \mathrm{C} ; 30$ cycles of $1 \mathrm{~min}$ at $94^{\circ} \mathrm{C}, 1 \mathrm{~min}$ at $55^{\circ} \mathrm{C}$, and $1.5 \mathrm{~min}$ at $72^{\circ} \mathrm{C}$; and a final extension step of $5 \mathrm{~min}$ at $72^{\circ} \mathrm{C}$. Archaeal community PCR amplification for clone analysis was conducted using the following primer combination: $21 \mathrm{~F}$ (5'-TCCGGTTGATCCYGSCRG-3') and 915R (5'-GTGCTCCCCCGCCAATTCCT-3') (Yan et al., 2012). The PCR regimen comprised: 10 min initial denaturing at $94^{\circ} \mathrm{C} ; 30$ cycles of 1 min at $93^{\circ} \mathrm{C}, 1 \mathrm{~min}$ at $50^{\circ} \mathrm{C}$, and $1.5 \mathrm{~min}$ at $72^{\circ} \mathrm{C}$; and a final extension step of $5 \mathrm{~min}$ at $72^{\circ} \mathrm{C}$. The products were examined by electrophoresis on $1 \%$ agarose gels before further analysis.

\section{Analysis of the 16S rRNA gene clone library and phylogenesis}

The PCR products were ligated into a pGEM-T easy vector (Promega, USA) according to the manufacturer protocol after purification using a TIANgel Midi purification kit (Tiangen Biotech, Beijing, China). Thirty-four clones from 500 white colonies and eight clones from 
300 white colonies that produced a single band with different melting positions were randomly picked for bacterial and archaeal sequence analysis, respectively. Sequence similarity searches were performed using the BLAST database in GenBank (http://www.ncbi.nlm.nih.gov/ BLAST/). The tree was constructed with the MEGA 4.0 software, using the neighbor-joining method (Zhao et al., 2013).

\section{Nucleotide sequence accession numbers}

The 42 partial 16S rDNA sequences obtained in this study were deposited at GenBank and assigned accession numbers KF550875-KF550909 and KF699851-KF699857.

\section{Biogas and chemical analysis}

Total solids (TS) and VS were determined according to standard methods (APHA, 1998). The $\mathrm{pH}$ values were measured using a Model B-712 pH meter (Horiba, Japan). The biogas volume was determined by the water displacement method and analyzed using a GA2000 gas analyzer (Geotech, UK) to determine methane content. The total nitrogen and carbon contents were determined using a multi C/N 3100 elemental analyzer (Analytik Jena, $\mathrm{UK})(\mathrm{C} / \mathrm{N}$ is the ratio of total carbon to total nitrogen). Lipid content was determined by the Soxhlet method with petroleum ether as the eluent (Yu et al., 2008). Protein content was determined by the modified Lowry method, using casein (Shanghai Sangon Biotechnology Co., Ltd., China) as the standard. Carbohydrate content was determined by deducting the protein and lipid contents from the total VS (Li et al., 2010).

\section{RESULTS}

\section{Domestication in 20-L digester}

The methane production, methane content, and $\mathrm{pH}$ values were recorded each day during the 36-day domestication process. Biogas yield and methane content can be used as indicators for monitoring reactor operation conditions (Michaud et al., 2002). Figure 1A and B show that methane production and methane content gradually increased during the first 20 days and then stabilized at approximately $4000 \mathrm{~mL}$ and $60 \%$, respectively. The anaerobic process is extremely sensitive to $\mathrm{pH}$, with an optimum $\mathrm{pH}$ range of 6.5-8.0 (Patel and Madamwar, 2000). As shown in Figure 1C, pH rapidly dropped from 7.5 to 5.9 on the second day, slowly recovered to 7.0 on the seventh day, and then stabilized at 7.0-7.1. Thus, the anaerobic digestion system effectively and stably digested FW after 36 days of domestication.

\section{Anaerobic digestion in 1-L digesters}

As shown in Figure 2, the $\mathrm{pH}$ changes in the $\mathrm{AD}$ process following inoculation with SS and DS were significantly different. The $\mathrm{pH}$ decreased rapidly and then stabilized at 4.0 from Day 4 when the reactor was inoculated with SS. In contrast, the $\mathrm{pH}$ decreased to 6.0 on the first day, but rose to 7.0 on the eighth day when the reactor was inoculated with DS. This indicates that organic acids produced by acid-forming bacteria can be utilized by methane-

Genetics and Molecular Research 15 (3): gmr.15038417 
forming archaea in a timely manner, resulting in a stable $\mathrm{pH}$ range suitable for FW AD. Therefore, inoculation with DS can enhance AD system stability.

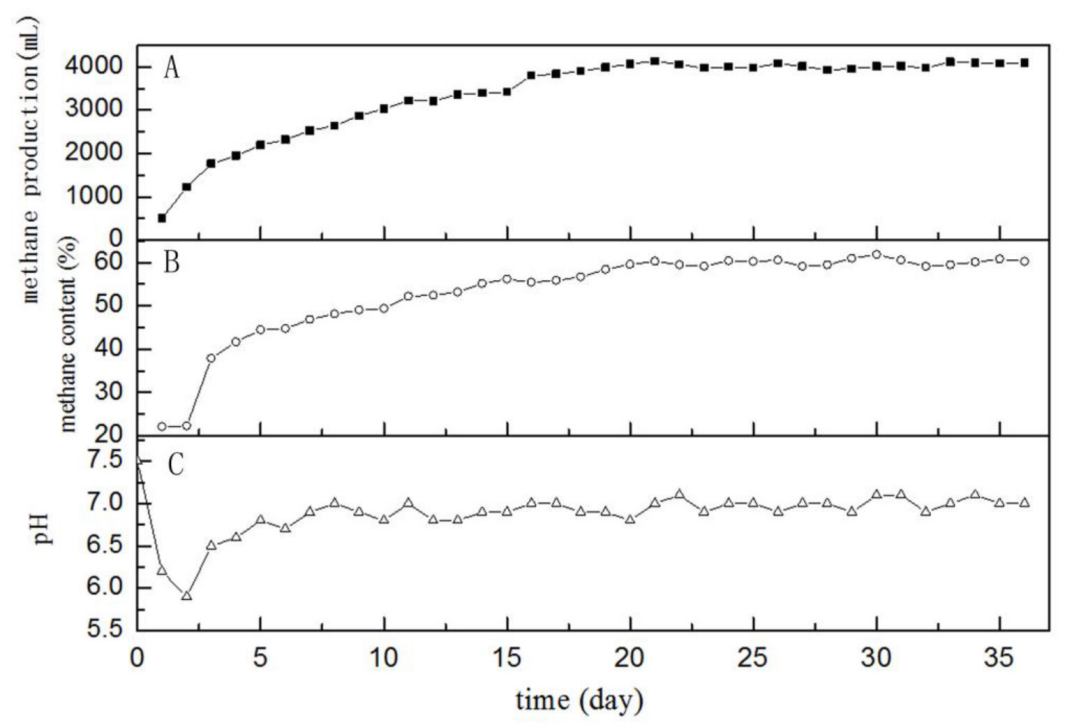

Figure 1. Daily methane production (A), methane content $(\mathbf{B})$, and $\mathrm{pH}(\mathbf{C})$ changes during the domestication process.

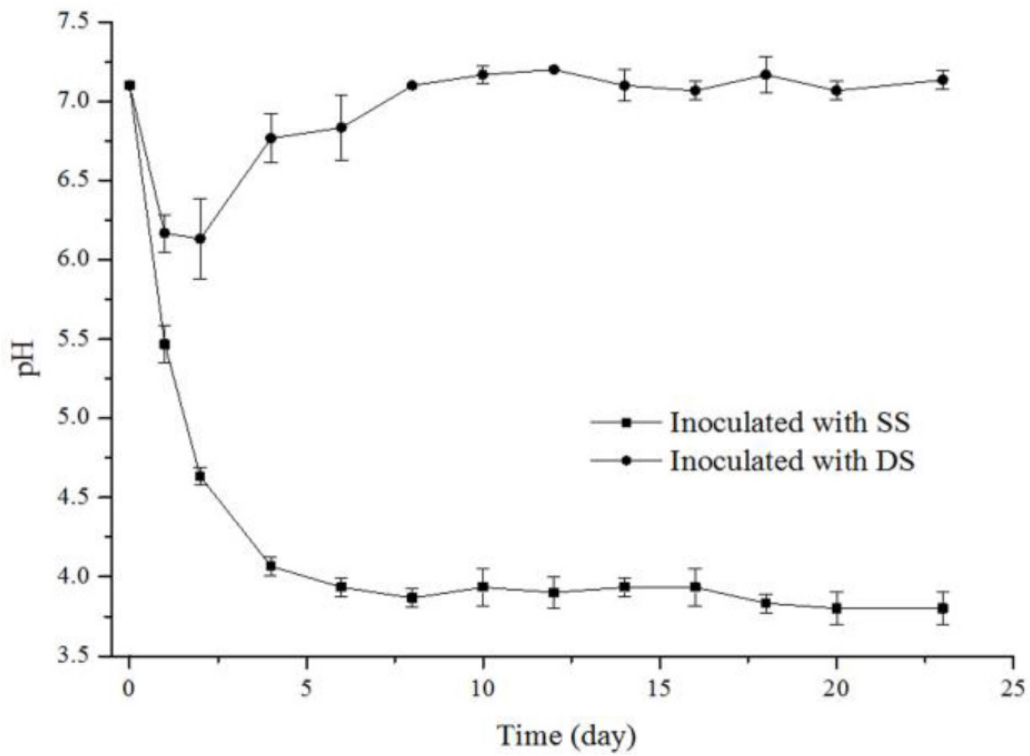

Figure 2. $\mathrm{pH}$ changes during the anaerobic digestion of food waste. Values are reported as means \pm standard deviation of triplicate samples. $\mathrm{SS}=$ seed sludge; $\mathrm{DS}=$ domestication sludge.

Genetics and Molecular Research 15 (3): gmr.15038417 
Figure 3 shows the changes in cumulative methane production following inoculation with SS and DS. The cumulative methane yield inoculation with DS increased and reached $292.2 \pm 9.8 \mathrm{~mL} / \mathrm{gVS}$ on Day 23. However, there was almost no methane yield from the reactors inoculated with SS. The final accumulative methane yield was $8.3 \mathrm{~mL} / \mathrm{gVS}$. The results indicate that the process of FW AD at an OLR of $20 \mathrm{~g} \cdot \mathrm{L}^{-1} \cdot \mathrm{day}^{-1}$ can be used to successfully initiate and manage FW if the reactor is inoculated with DS. Therefore, a high-quality domesticated inoculum is essential for the FW AD process.

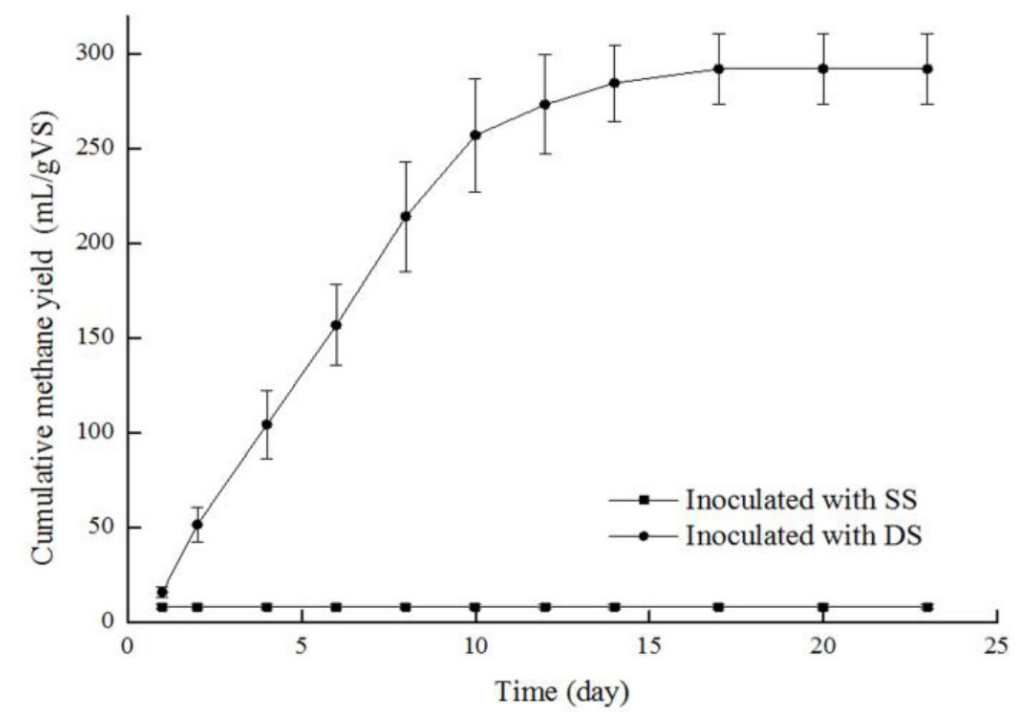

Figure 3. Cumulative methane production changes during the anaerobic digestion of food waste. Values are reported as means \pm standard deviation of triplicate samples. SS $=$ seed sludge; DS $=$ domestication sludge.

\section{Clone library analysis of the bacterial community}

SS and DS samples were investigated by constructing a 16S rRNA gene clone library. Figures 4 and 5 show the bacterial community phylogenetic trees based on complete $16 \mathrm{~S}$ rRNA clone gene sequences. Twenty classified operational taxonomic units (OTUs) were identified in the SS; the dominant species were from Clostridia (49.3\%), Bacteroidales (19.5\%), and Anaerolinaceae $(8.1 \%)$. The dominant communities in animal guts and the biogas reactor comprised Firmicutes and Bacteroidetes species (Li et al., 2015). Fourteen classified OTUs were identified in the DS.

The dominant species in the SS were from Clostridia (49.3\%), Bacteroidales (19.5\%), and Anaerolinaceae $(8.1 \%)$; the dominant species in the DS were from Anaerolinaceae (49.0\%), Clostridia (28.4\%), and Bacteroidales (9.1\%).

As shown in Figure 6A and B, domestication affected the abundance and appearance of new species. Clone DBB-19 (Sedimentibacter saalensis AJ404680.1, attributed to Burkholderiaceae) and some uncultured bacterium clones, i.e., DBB-1 (uncultured bacterium GQ458248.1), DBB-7 (uncultured bacterium EU381491.1), and DBB-14 (uncultured 


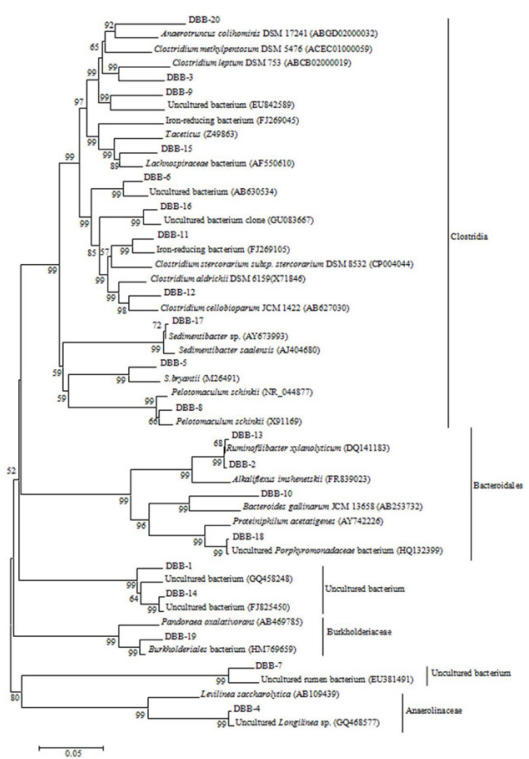

Figure 4. Phylogenetic tree of bacterial 16S rDNA sequences in seed sludge (SS). The bacterial 16S rDNA sequences of the SS isolates were aligned along with their representative sequences from GenBank using the ClustalW $^{\circ}$ program. The phylogenetic tree was constructed using the neighbor-joining method in MEGA 4.0, and the neighbor-joining tree was drawn with the TreeView program. Bootstrap values are indicated at the branch.

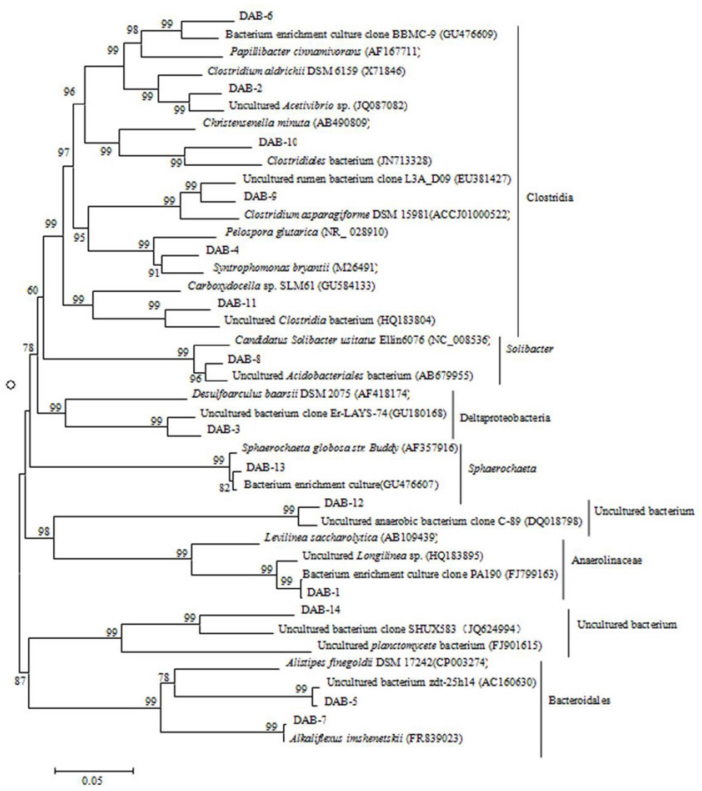

Figure 5. Phylogenetic tree of bacterial 16S rDNA sequences in domestication sludge (DS). The bacterial 16S rDNA sequences of the isolates in DS were aligned along with their representative sequences from GenBank using the ClustalW ${ }^{\circ}$ program. The phylogenetic tree was constructed using the neighbor-joining method in MEGA 4.0, and the neighbor-joining tree was drawn with the TreeView program. Bootstrap values are indicated at the branch.

Genetics and Molecular Research 15 (3): gmr.15038417 
bacterium FJ825450.1), disappeared. Clones DAB-3 (Desulfoarculus baarsii AF418174.1, attributed to Deltaproteobacteria), DAB-8 (Candidatus Solibacter usitatus NC_008536.1, attributed to Solibacter), and DAB-13 (Sphaerochaeta globosa str. Buddy AF357916.1, attributed to Sphaerochaeta) were only identified in the DS.

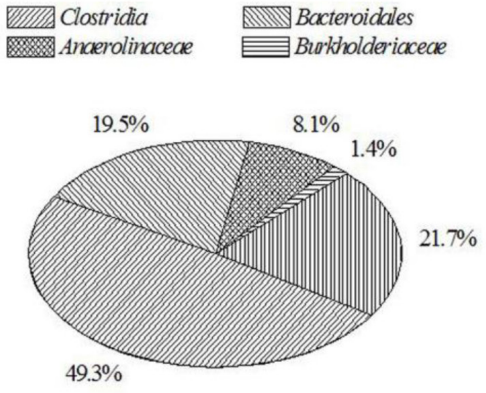

A

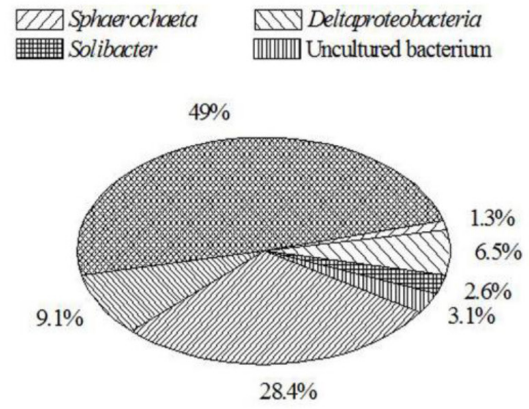

B

Figure 6. Effects of domestication on the composition of bacterial communities in seed sludge (A) and domestication sludge (B).

\section{Clone library analysis of archaeal community}

SS and DS samples were investigated by constructing a 16S rRNA gene clone library. Figures 7 and 8 show archaeal community phylogenetic trees based on complete 16S rRNA gene sequences of the clones. Three classified OTUs were identified in the SS; the dominant methanogen genus was Methanosaeta (94.3\%). Five classified OTUs were identified in the DS; the dominant-related genera were Methanosaeta (74.3\%) and Methanoculleus (21.7\%).

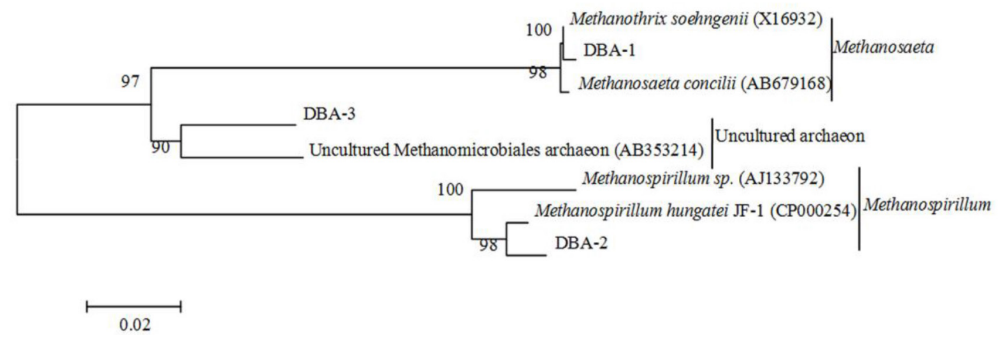

Figure 7. Phylogenetic tree of Archaea 16S rDNA sequences in seed sludge (SS). The Archaea 16S rDNA sequences of the isolates in SS were aligned along with their representative sequences from GenBank using the ClustalW $W^{\odot}$ program. The phylogenetic tree was constructed using the neighbor-joining method in MEGA 4.0, and the neighbor-joining tree was drawn with the TreeView program. Bootstrap values are indicated at the branch.

As shown in Figure 9A and B, there were more methanogenic archaea in the DS than in the SS when the inoculum was domesticated. Methanomicrobiale-related populations (Methanoculleus) colonized the DS, i.e., clones DAA-2 (M. palmolei DSM 4273 NR_028253.1) and DAA-3 (M. chikugoensis AB038795.1); they were not identified in the 
SS. Two other clones, DBA-2 (Methanospirillum hungatei JF-1 CP000254.1) and DAA-4 (Methanospirillum hungatei JF-1 CP000254.1), attributed to Methanomicrobiales, colonized the DS. The authors of previous studies have reported that when Methanomicrobiale species are abundant in the system they protect the reactor from external environment shocks, and promote successful operation and stability (De Vrieze et al., 2012; Lins et al., 2012). From the phylogenetic trees, we found that Methanosaeta was dominant in both SS and DS. Previous reports have illustrated that Methanosaeta species are likely to play an important role in medium-temperature anaerobic reactors, and that acetoclastic methanogenesis is the main pathway for methane production (Metje and Frenzel, 2007; Stets et al., 2014). In addition, a clone attributed to Thaumarchaeota (Candidatus Nitrosocaldus yellowstonii EU239960.1) was only identified in the DS.

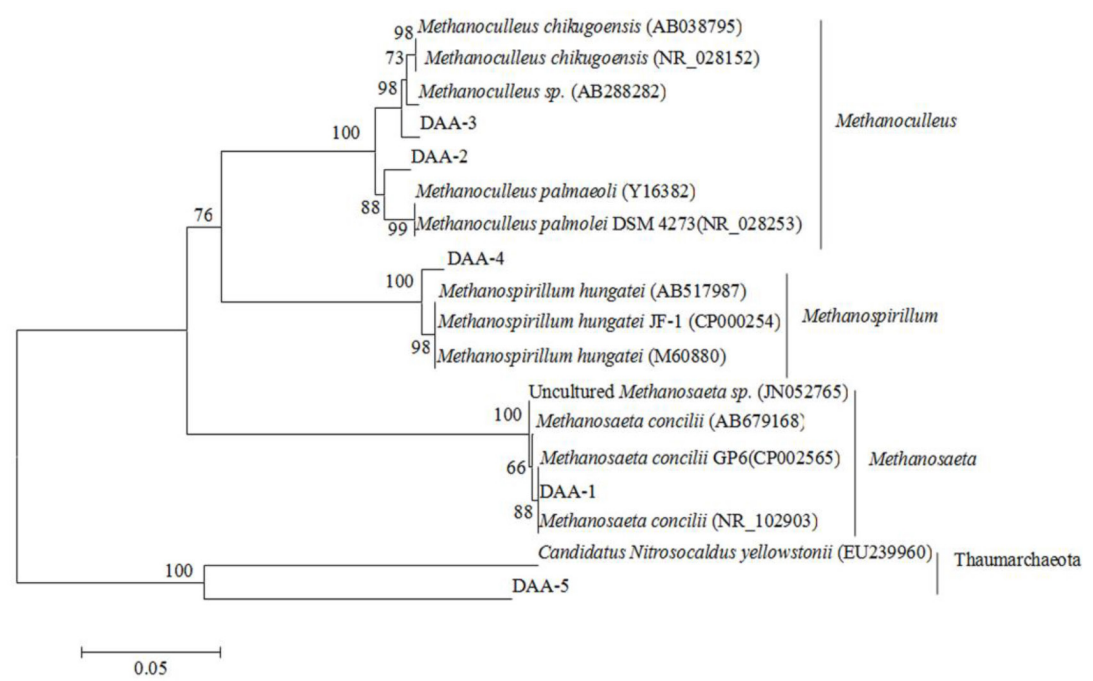

Figure 8. Phylogenetic tree of Archaea 16S rDNA sequences in domestication sludge (DS). The Archaea 16S rDNA sequences of the isolates in DS were aligned along with their representative sequences from GenBank using the ClustalW ${ }^{\circ}$ program. The phylogenetic tree was constructed using the neighbor-joining method in MEGA 4.0, and the neighbor-joining tree was drawn with the TreeView program. Bootstrap values are indicated at the branch.

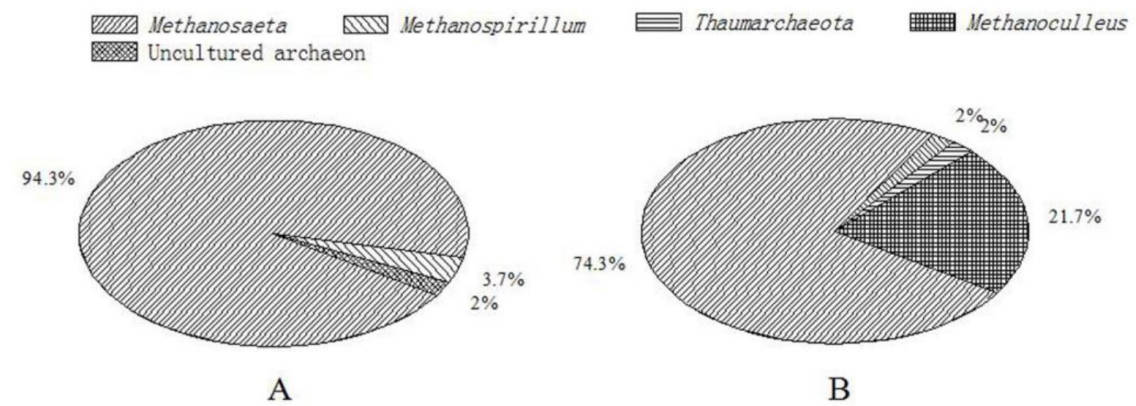

Figure 9. Effects of domestication on the composition of Archaea communities in seed sludge (A) and domestication sludge (B).

Genetics and Molecular Research 15 (3): gmr.15038417 


\section{DISCUSSION}

Start-up is an important and relatively slow step in anaerobic treatment, and controlling the start-up process is very difficult. The authors of a number of studies have suggested that a successful start-up is necessary for the creation of a proper microbial community that conforms to the desired physiological functions (Moset et al., 2014; Tian et al., 2015). Appropriate inocula guarantee an anaerobic process with a stable and rapid start-up. The domestication process changes the inoculum microorganism community composition, enabling the community to adapt to different feedstocks, temperatures, and substrate concentrations during AD. When inoculated with acclimated sludge, daily cotton stalk AD and cumulative biogas production were improved (Bai et al., 2010). Ma et al. (2007) reported that the dominant microorganism in activated sludge changed from Sphaerita to single and distributed rod cells during domestication by FW addition. Until now, there has been no study of the effects of domestication on microorganism population composition.

In this study, $\mathrm{AD}$ of $\mathrm{DM}$ residue was domesticated by FW addition for 36 days. After 20 days of treatment, the daily methane production, methane content, and $\mathrm{pH}$ remained stable at $4000 \mathrm{~mL}, 60 \%$, and 7.0, respectively. When inoculated with domestication sludge, FW AD at an OLR of $20 \mathrm{~g} \cdot \mathrm{L}^{-1} \cdot$ day $^{-1}$ started quickly, maintained a stable AD process, and achieved a methane yield of $292.2 \mathrm{~mL} / \mathrm{gVS}$. Zhang et al. (2007) reported that the FW methane yield was $445 \mathrm{~mL} / \mathrm{gVS}$ after 28 days of FW AD at $50^{\circ} \mathrm{C}$. Cho and Park (1995) studied the characteristics at medium temperature of two-phase $\mathrm{FW}$ anaerobic fermentation and obtained a methane yield of $472 \mathrm{~mL} / \mathrm{gVS}$. The difference in biogas production rates between these studies can be explained by different material compositions and fermentation processes. In a batch anaerobic fermentation, TS concentration of FW greater than $2.25 \%$ will result in rancidity (Zhang et al., 2014b). The TS concentration of FW used in the batch test of this study was close to the upper limit at $2.2 \%$. Diluting the FW from 20 to $2 \%$, transforming the solid waste to high concentrations waste water, increases the processing costs. Further study is needed to ensure an efficient and stable $\mathrm{AD}$ process at high concentrations.

$\mathrm{AD}$ is the biodegradation process of organic matter. The bacterial composition affects volatile fatty acid formation, which influences the subsequent methanation (Switzenbaum et al., 1990). In this study, domestication changed the bacterium composition. The cellulosedegradation species were the dominant bacteria in the SS, whereas protein-degradation species belonging to the family Anaerolineaceae were the dominant bacteria in the DS. The domestication process decreased the population of cellulose-degradation species. The protein contents of FW and DM used in this study were 14.5 and $2 \%$, respectively. Therefore, the proportion of the populations belonging to Anaerolineaceae in the clone library increased, which was consistent with the substrate composition changes.

Domestication also changed the structure and composition of Archaea. Two distinct methanogen groups, acetoclastic and hydrogenotrophic, play major roles in producing methane (Wirth et al., 2015). Because hydrogenotrophic methanogens are more resistant to toxic substances such as ammonia than acetoclastic methanogens, conditions that favor hydrogenotrophic methanogen domination in $\mathrm{AD}$ systems are desirable. It is also possible that acetoclastic methanogen populations decrease if free ammonia conditions are maintained above $0.37 \mathrm{~g} / \mathrm{L}$ (Godina et al., 2012). Protein decomposition produces volatile acids and ammonia nitrogen when ammonia nitrogen concentrations reach $2000 \mathrm{mg} / \mathrm{L}$, thereby

Genetics and Molecular Research 15 (3): gmr.15038417 
inhibiting methanation (Liu et al., 2012). Species belonging to the phylum Thaumarchaeota can metabolize ammonia and reduce the ammonia concentration in the reactor (de la Torre et al., 2008). Those Thaumarchaeota species appeared in the DS, and may have reduced the negative effects of ammonia nitrogen on the methanogenesis process, enhancing methane production.

Domestication changed the composition and proportion of the bacterial and archaeal community in the sludge; this change in the dominant microbial community is consistent with substrate changes. In this experiment, an efficient inoculum for food waste anaerobic digestion was obtained by domestication for 36 days. The DS inoculation promoted a stable and efficient AD process at an OLR of $20 \mathrm{gVS} / \mathrm{L}$, and improved the food waste biogas production performance.

\section{Conflicts of interest}

The authors declare no conflict of interest.

\section{ACKNOWLEDGMENTS}

Research supported by the Chinese National Science and Technology Department Project (\#2013BAD21B01; \#2012BAD12B05-3), the Scientific Research Sharing Foundation for Introduced Talents in HLBU (\#XDB2015-26), the Program of Science and Technology Innovation Teams Building in Heilongjiang Province (\#2012TD006), and the Science and Technology Planning Project of Heilongjiang Province (\#GZ11B108).

\section{REFERENCES}

APHA (1998). Standard methods for examination of water and wastewater. 20th edn. American Public Health Association, Washington DC.

Bai Y, Li W, Chen C and Liao P (2010). Biological pretreatment of cotton stalks and domestication of inocula in biogas fermentation. Microbiol. China 37: 513-519.

Carlsson M, Naroznova I, Møller J, Scheutz C, et al. (2015). Importance of food waste pre-treatment efficiency for global warming potential in life cycle assessment of anaerobic digestion systems. Resour. Conserv. Recycling 102: 58-66. http://dx.doi.org/10.1016/j.resconrec.2015.06.012

Chen E and Gu XY (2012). Advance in disposal and resource technology of food waste. Environ. Study Monit. 3: 57-61.

Chen GY, Liu G, Yan BB, Shan R, et al. (2016). Experimental study of co-digestion of food waste and tall fescue for biogas production. Renew. Energy 88: 273-279. http://dx.doi.org/10.1016/j.renene.2015.11.035

Cho JK and Park SC (1995). Biochemical methane potential and solid state anaerobic digestion of Korean food wastes. Bioresour. Technol. 52: 245-253. http://dx.doi.org/10.1016/0960-8524(95)00031-9

de la Torre JR, Walker CB, Ingalls AE, Könneke M, et al. (2008). Cultivation of a thermophilic ammonia oxidizing archaeon synthesizing crenarchaeol. Environ. Microbiol. 10: 810-818. http://dx.doi.org/10.1111/j.1462-2920.2007.01506.x

De Vrieze J, Hennebel T, Boon N and Verstraete W (2012). Methanosarcina: the rediscovered methanogen for heavy duty biomethanation. Bioresour. Technol. 112: 1-9. http://dx.doi.org/10.1016/j.biortech.2012.02.079

Elbeshbishy E, Nakhla G and Hafez H (2012). Biochemical methane potential (BMP) of food waste and primary sludge: influence of inoculum pre-incubation and inoculum source. Bioresour. Technol. 110: 18-25. http://dx.doi. org/10.1016/j.biortech.2012.01.025

Godina A, McLaughlinb JW, Websterc KL, Packalen M, et al. (2012). Methane and methanogen community dynamics across a boreal peatland nutrient gradient. Soil Biol. Biochem. 48: 96-105. http://dx.doi.org/10.1016/j. soilbio.2012.01.018

Jain S, Jain S, Wolf IT, Lee J, et al. (2015). A comprehensive review on operating parameters and different pretreatment

Genetics and Molecular Research 15 (3): gmr.15038417 
methodologies for anaerobic digestion of municipal solid waste. Renew. Sustain. Energy Rev. 52: 142-154. http:// dx.doi.org/10.1016/j.rser.2015.07.091

Kong X, Xu S, Liu J, Li H, et al. (2016). Enhancing anaerobic digestion of high-pressure extruded food waste by inoculum optimization. J. Environ. Manage. 166: 31-37. http://dx.doi.org/10.1016/j.jenvman.2015.10.002

Kröber M, Bekel T, Diaz NN, Goesmann A, et al. (2009). Phylogenetic characterization of a biogas plant microbial community integrating clone library 16S-rDNA sequences and metagenome sequence data obtained by 454-pyrosequencing. J. Biotechnol. 142: 38-49. http://dx.doi.org/10.1016/j.jbiotec.2009.02.010

Li L, He Q, Ma Y, Wang X, et al. (2015). Dynamics of microbial community in a mesophilic anaerobic digester treating food waste: Relationship between community structure and process stability. Bioresour. Technol. 189: 113-120. http://dx.doi.org/10.1016/j.biortech.2015.04.015

Li R, Chen S and Li X (2010). Biogas production from anaerobic co-digestion of food waste with dairy manure in a two-phase digestion system. Appl. Biochem. Biotechnol. 160: 643-654. http://dx.doi.org/10.1007/s12010-009-8533-z

Lins P, Reitschuler C and Illmer P (2012). Development and evaluation of inocula combating high acetate concentrations during the start-up of an anaerobic digestion. Bioresour. Technol. 110: 167-173. http://dx.doi.org/10.1016/j. biortech.2012.01.145

Liu J, Luo J, Zhou J, Liu Q, et al. (2012). Inhibitory effect of high-strength ammonia nitrogen on bio-treatment of landfill leachate using EGSB reactor under mesophilic and atmospheric conditions. Bioresour. Technol. 113: 239-243. http:// dx.doi.org/10.1016/j.biortech.2011.11.114

Ma L, Wang DH, Yang WJ, Zeng CM, et al. (2007). Domestication of inoculums in treating food waste by thermophilic anaerobic digestion. Trans. Chin. Soc. Agric. Eng. 23: 203-207.

Metje M and Frenzel P (2007). Methanogenesis and methanogenic pathways in a peat from subarctic permafrost. Environ. Microbiol. 9: 954-964. http://dx.doi.org/10.1111/j.1462-2920.2006.01217.x

Michaud S, Bernet N, Buffière P, Roustan M, et al. (2002). Methane yield as a monitoring parameter for the start-up of anaerobic fixed film reactors. Water Res. 36: 1385-1391. http://dx.doi.org/10.1016/S0043-1354(01)00338-4

Moset V, Bertolini E, Cerisuelo A, Cambra M, et al. (2014). Start-up strategies for thermophilic anaerobic digestion of pig manure. Energy 74: 389-395. http://dx.doi.org/10.1016/j.energy.2014.07.003

Nizami AS, Orozco A, Groom E, Dieterich B, et al. (2012). How much gas can we get from grass? Appl. Energy 92: 783 790. http://dx.doi.org/10.1016/j.apenergy.2011.08.033

Patel $\mathrm{H}$ and Madamwar D (2000). Biomethanation of low $\mathrm{pH}$ petrochemical wastewater using up-flow fixed-film anaerobic bioreactors. World J. Microbiol. Biotechnol. 16: 69-75. http://dx.doi.org/10.1023/A:1008999420741

Stets MI, Etto RM, Galvão CW, Ayub RA, et al. (2014). Microbial community and performance of slaughterhouse wastewater treatment filters. Genet. Mol. Res. 13: 4444-4455. http://dx.doi.org/10.4238/2014.June.16.3

Supaphol S, Jenkins SN, Intomo P, Waite IS, et al. (2011). Microbial community dynamics in mesophilic anaerobic co-digestion of mixed waste. Bioresour. Technol. 102: 4021-4027. http://dx.doi.org/10.1016/j.biortech.2010.11.124

Suwannarat J and Ritchie RJ (2015). Anaerobic digestion of food waste using yeast. Waste Manag. 42: 61-66. http:// dx.doi.org/10.1016/j.wasman.2015.04.028

Switzenbaum MS, Giraldo-Gomez E and Hickey RF (1990). Monitoring of the anaerobic methane fermentation process. Enzyme Microb. Technol. 12: 722-730. http://dx.doi.org/10.1016/0141-0229(90)90142-D

Tian Z, Zhang Y, Li Y, Chi Y, et al. (2015). Rapid establishment of thermophilic anaerobic microbial community during the one-step startup of thermophilic anaerobic digestion from a mesophilic digester. Water Res. 69: 9-19. http:// dx.doi.org/10.1016/j.watres.2014.11.001

Wirth R, Lakatos G, Böjti T, Maróti G, et al. (2015). Metagenome changes in the mesophilic biogas-producing community during fermentation of the green alga Scenedesmus obliquus. J. Biotechnol. 215: 52-61. http://dx.doi.org/10.1016/j. jbiotec.2015.06.396

Xu CQ, Shi WX, Hong JL, Zhang FF, et al. (2015). Life cycle assessment of food waste-based biogas generation. Renew. Sustain. Energy Rev. 49: 169-177. http://dx.doi.org/10.1016/j.rser.2015.04.164

Yan L, Gao Y, Wang Y, Liu Q, et al. (2012). Diversity of a mesophilic lignocellulolytic microbial consortium which is useful for enhancement of biogas production. Bioresour. Technol. 111: 49-54. http://dx.doi.org/10.1016/j. biortech.2012.01.173

Yang LL, Huang Y, Zhao MX, Huang ZX, et al. (2015). Enhancing biogas generation performance from food wastes by high-solids thermophilic anaerobic digestion: Effect of pH adjustment. Int. Biodet. Biodegrad. 105: 153-159. http:// dx.doi.org/10.1016/j.ibiod.2015.09.005

Yu GH, He PJ, Shao LM and Zhu YS (2008). Extracellular proteins, polysaccharides and enzymes impact on sludge aerobic digestion after ultrasonic pretreatment. Water Res. 42: 1925-1934. http://dx.doi.org/10.1016/j.watres.2007.11.022

Zhang CS, Su HJ, Baeyens J and Tan TW (2014a). Reviewing the anaerobic digestion of food waste for biogas production.

Genetics and Molecular Research 15 (3): gmr.15038417 
Renew. Sustain. Energy Rev. 38: 383-392. http://dx.doi.org/10.1016/j.rser.2014.05.038

Zhang QF, Yang LH, Chen JX, Kong XQ, et al. (2014b). Effect of organic loading on continuous anaerobic fermentation parameters of kitchen waste. China Biogas 32: 27-31.

Zhang R, El-Mashad HM, Hartman K, Wang F, et al. (2007). Characterization of food waste as feedstock for anaerobic digestion. Bioresour. Technol. 98: 929-935. http://dx.doi.org/10.1016/j.biortech.2006.02.039

Zhang W, Zhang L and Li A (2015). Anaerobic co-digestion of food waste with MSW incineration plant fresh leachate: process performance and synergistic effects. Chem. Eng. J. 259: 795-805. http://dx.doi.org/10.1016/j.cej.2014.08.039

Zhao H, Li J, Li J, Yuan X, et al. (2013). Organic loading rate shock impact on operation and microbial communities in different anaerobic fixed-bed reactors. Bioresour. Technol. 140: 211-219. http://dx.doi.org/10.1016/j. biortech.2013.04.027

Zhou L, Li WZ and Shi CQ (2004). The study characteristics of the anaerobic fermentation for the sludge. J. Agric. Mechanization Res. 3: 152-153.

Genetics and Molecular Research 15 (3): gmr.15038417 